UDK: 636.8.09:616.5-002.828

DOI: 10.2478 /acve-2020-0038

Case report

\title{
URTICARIA PIGMENTOSA DUE TO MICROSPORUM CANIS INFECTION IN A SPHYNX CAT - CASE REPORT
}

\author{
SZCZEPANIK Marcin ${ }^{1 *}$, WILKOLEK Piotr ${ }^{1}$, KALISZ Grzegorz ${ }^{2}$, ŚMIECH Anna ${ }^{3}$ \\ ${ }^{1}$ Subdepartment of Clinical Diagnostics and Veterinary Dermatology, Faculty of Veterinary Medicine, \\ University of Life Sciences in Lublin, Lublin, Poland; ${ }^{2}$ Department of Biopharmacy, Faculty of \\ Pharmacy, Medical University of Lublin, ul. W. Chodzki 4a, Lublin, Poland; ${ }^{3}$ Department of Pathology, \\ University of Life Science in Lublin, 20-620 Lublin, Głęboka 30, Poland
}

(Received 20 May, Accepted 28 September 2020)

A two-year-old Sphynx cat, an unneutered female with multiple erythematous papules with hyperpigmentation was presented. In skin biopsy, in the dermis, well differentiated monomorphic mast cells were found. Fungal culture was positive for Microsporum canis. Diagnosis of urticaria pigmentosa following $M$. canis infection was made. The animal was successfully treated with itraconazole orally and shampoo containing chlorhexidine and miconazole. To the authors' knowledge, this is the first reported case of urticaria pigmentosa following the dermatophyte infection in a Sphynx cat.

Key words: cats, dermatology, Microsporum canis, urticaria pigmentosa

\section{INTRODUCTION}

Mast cell proliferation may occur as a mast cell tumor, cutaneous or systemic mastocytosis or mast cell leukemia [1]. Mast cell tumor, as well as cutaneous and systemic mastocytosis have been described in cats [2-4].

Mast cell tumors are quite common in this species, while cutaneous mastocytosis by contrast is rare. It appears either as diffused cutaneous mastocytosis or as urticaria pigmentosa (eosinophilic/mastocytic dermatitis). Urticaria pigmentosa is a generalized cutaneous form of mast cell proliferation, typical for hairless or hypotrihosis cats like the Devon Rex and Sphynx breeds, although it has also been described in the European Shorthair [5-9]. It is presumed that the cause is genetic, which was evidenced by its occurrence in the two abovementioned species of cats, and its occurrence in directly related individuals [5]. It develops as a consequence of mast cell proliferation, probably associated with hypersensitivity reactions but its exact causes are not fully known yet. It is usually observed in young animals, and the typical symptoms are numerous erythematous and pigmented macules and papules on the head, limbs, trunk and neck [5]. Histopathological examination of the skin from affected cats reveals

\footnotetext{
*Corresponding author: e-mail: kryll@poczta.onet.pl
} 
perivascular or diffuse cellular infiltrations in the superficial and deep dermis. The infiltrate is composed of mast cells and (most often) of a small number of eosinophils and neutrophils [9]. In addition, accumulation of pigment in the keratinocytes has been reported [7].

\section{CASE PRESENTATION}

Urticaria pigmentosa was diagnosed in a two-year-old Sphynx cat, an unneutered female. About 3 weeks before presentation to the clinic, the cat was observed to develop numerous macules, papules and individual pustules located on the trunk, limbs and abdomen. There were no manifestation from other body systems, and the cat had no previous history of abovementioned symptoms. The cat had been receiving the antibiotic (amoxicillin/clavulanic acid in a dosage of $25 \mathrm{mg} / \mathrm{kg}$ twice daily) for about 2 weeks for its skin lesions, but the treatment had no effect. During the clinical examination (after 2 weeks of unsuccessful treatment), the animal had numerous erythematous and pigmented macules, numerous papules and individual pustules. The lesions were abundant and were located in the largest number on the sides of the lateral thorax, abdominal regions and thighs (Fig. 1). On the head, they occurred in a small number. In addition, small alopecia covered with scales was found, located on the lateral surface of the right foot (distal parts of the limbs were covered with hair). No pruritus was observed in the animal. Wood's lamp examination revealed very pronounced fluorescence in places of erythematous and pigmented macules (Fig. 2), but not in the place of alopecia on the distal limb. Microscopic examination of hair collected from the alopecia revealed numerous arthrospores arranged around the hair. Fungal cultures on Sabouraud agar, revealed $M$. canis.

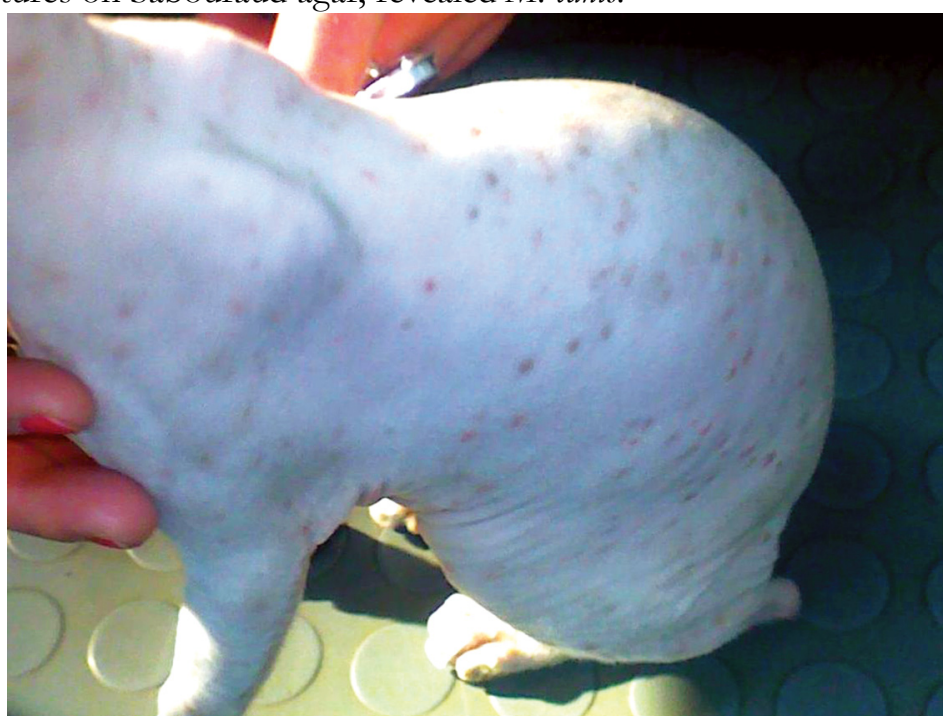

Figure 1. Numerous visible erythematous and pigmented macules and papules on the trunk, and thighs of the animal. 


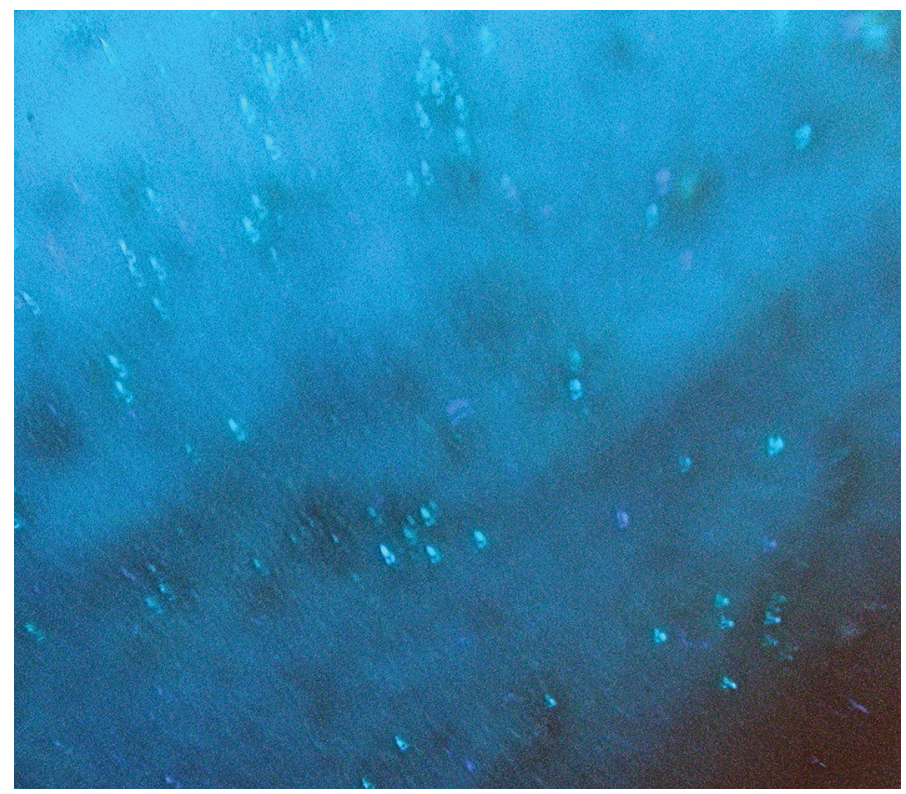

Figure 2. Wood's lamp examination, strong fluorescence visible at the site of efflorescence.

After local anesthesia with 1\% lignocaine and sedation with detomidine, one $6 \mathrm{~mm}$ punch biopsy was taken from a macula located on the dorsal surface of the thorax. Samples for histopathological examination were collected and fixed in 10\% formalin buffered to $\mathrm{pH}$ 7.2. Subsequently, tissue sections were dehydrated in increasing concentrations of alcohol solutions and acetone, immersed in xylene, and formed into paraffin blocks in a tissue processor. Tissue sections with a thickness of $4 \mu \mathrm{m}$ were prepared on a sliding microtome and placed on a microscope slide. Specimens for histopathological examination were stained with haematoxylin, eosin (HE stain) and with toluidine blue and observed under a light microscope.

Histopathology of the skin demonstrated a moderate to severe perivascular diffuse infiltrate in the superficial and deep dermis. The infiltrate was comprised mainly of a homogenous population of mast cells with smaller numbers of eosinophils and neutrophils (Fig. 3). Mast cells were well differentiated, with central nucleus, granular cytoplasm, and metachromatic granules staining positively with Toluidine blue stain (Fig. 4). A few large mast cells were present in the panniculus.

Based on the results of histopathological examination, microscopic examination of the hair and fungal cultures, the diagnosis of urticaria pigmentosa caused by dermatophyte infection was made. The animal was treated with $10 \mathrm{mg} / \mathrm{kg}$ itraconazole orally once daily, administered for 4 weeks. In addition, baths were used twice a week with a $2 \%$ miconazole and $2 \%$ chlorhexidine gluconate shampoo (Malaseb ${ }^{\circledR}$ shampoo, Dechra Veterinary Products, Shrewsbury, UK). After 2 months of combined treatment, the lesions completely disappeared (Fig.5). 


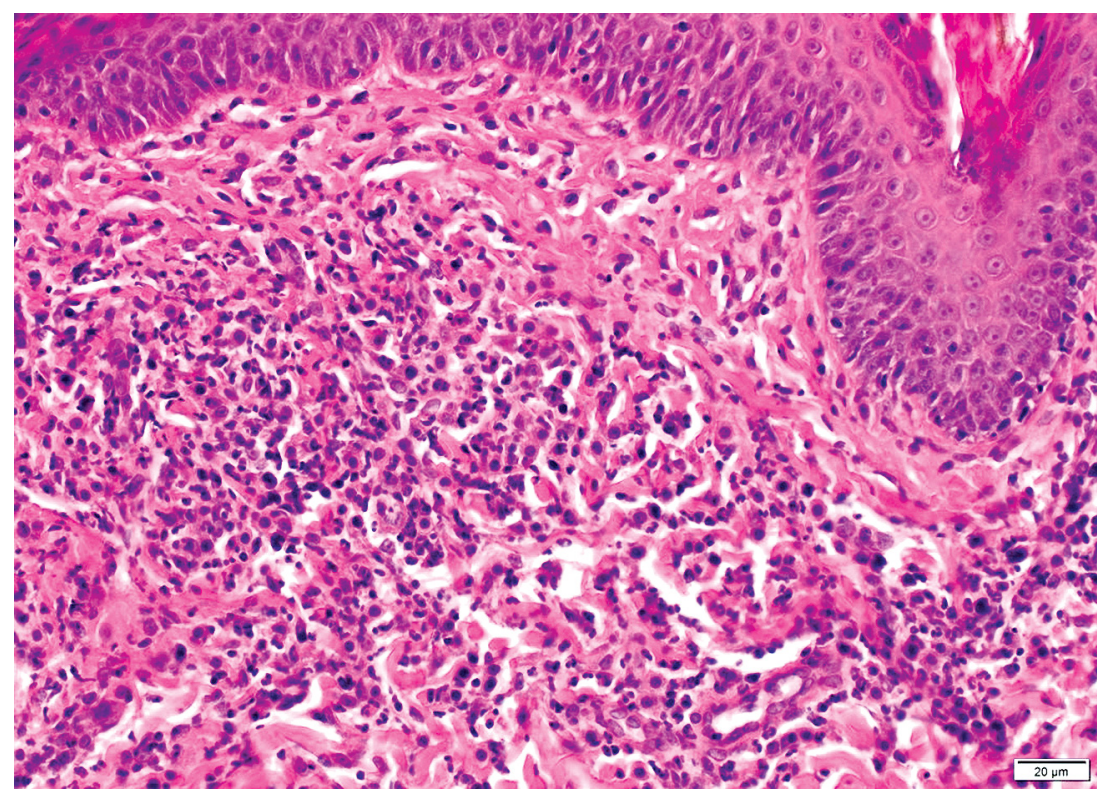

Figure 3. Histopathological image of urticaria pigmemntosa. Moderate to severe perivascular diffuse infiltrate in the superficial and deep dermis. The infiltrate was comprised mainly of a homogenous population of mast cells with a lower number of eosinophils and neutrophils (HE stain, x200 magnification).

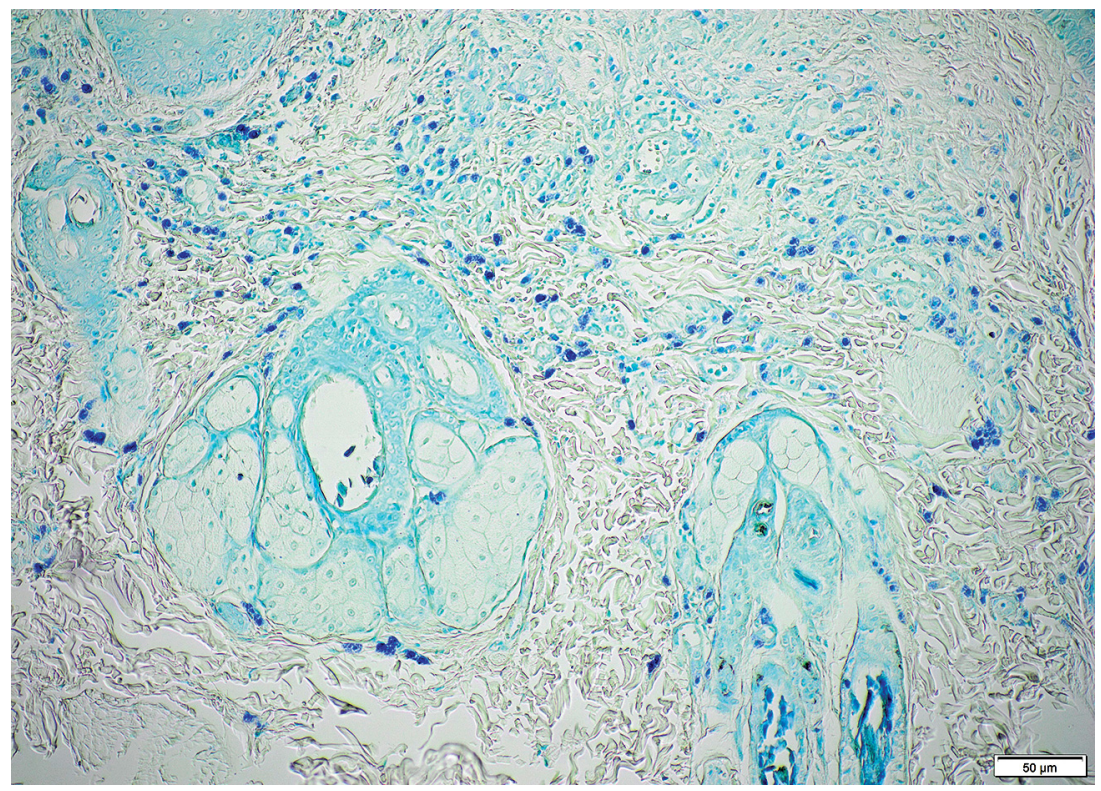

Figure 4. Infiltration of well differentiated mast cells in the dermis, cells with metachromatic granules staining positively with Toluidine blue. Mast cells were well differentiated, with central nucleus, granular cytoplasm, and metachromatic granules staining positively with Toluidine blue stain. A few large mast cells were present in the panniculus. (Toluidine blue stain; x100 magnification). 


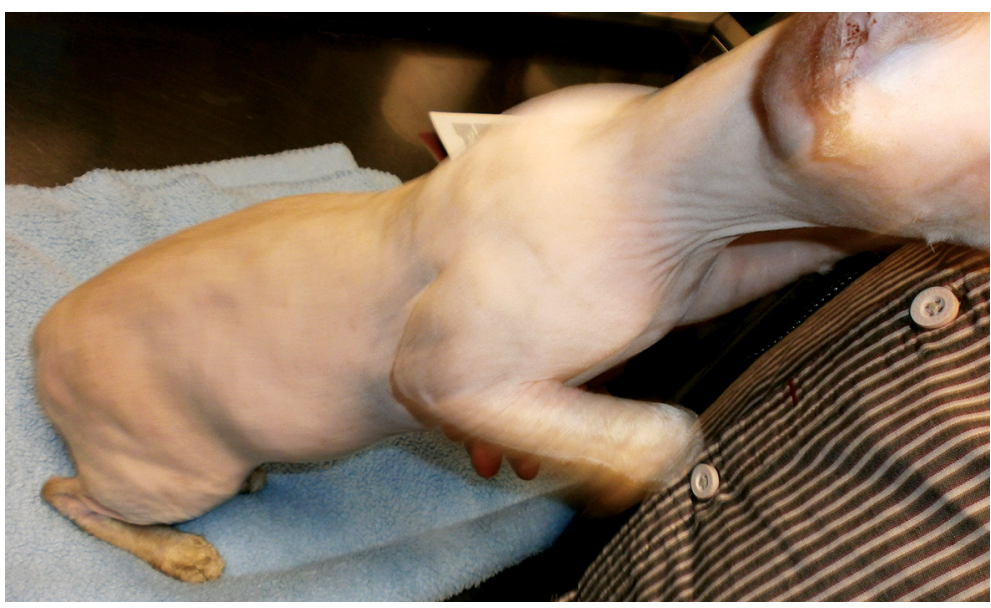

Figure 5. Cat after treatment - complete resolution of lesions.

\section{DISCUSSION}

The presented clinical case corresponds to urticaria pigmentosa, which is a typical disease for hairless or hypotrichotic cats such as Devon rex and Sphynx [7]. Dermatophytosis as the cause of urticaria pigmentosa has been described in three Devon rex cats [5]. The atypical form of dermatophytosis in such cats may be a result of the hypersensitivity reactions development to dermatophyte allergens. In the progression of urticaria pigmentosa, involvement of hypersensitivity reactions in its' formation is possible. It is known that the course of fungal infections also develops hypersensitivity to dermatophyte allergens, which may explain this particular case of the disease. The observed histopathological symptoms were similar to those observed in the course of urticaria pigmentosa, infection was confirmed independently by cultures and microscopy examinations of the hair. In the case of urticaria pigmentosa caused by M. canis infection in Devon rex cats, in one of the three cases no signs of dermatophytosis were found by histopathological examination [5].

In the presented case, urticaria pigmentosa was diagnosed as a secondary disease to M. canis infection which is why proper treatment of the primary disease was successful solely. All lesions resolved within 4 weeks period, until follow-up visit. Urticaria pigmentosa treatment is usually based on the oral administration of ciclosporin, glucocorticoids or antihistamines because of related hypersensitivity reactions $[6,8,9]$. The use of oclacitinib was reported as not effective in the treatment of this disease [8], while was effective in the course of diffuse cutaneous mastocytosis [10,11].

In conclusion in Sphynx cats, dermatophytosis should be considered as a possible cause of urticaria pigmentosa.The exclusion of fungal infection in the case of urticaria pigmentosa is crucial concerning the modality of disease treatment, where immunosuppressive drugs such as glucocorticoids or cyclosporine can be used, the use of which in the case of dermatophytosis is absolutely contraindicated $[6,8,9]$. 


\section{Authors' contributions}

SM made concept of study, material qualification, carrage of the study, analysis and interpretation of results and preparation of manuscript. WP helped in material qualification and preparation of manuscript. KG writing, reviewing and editing the manuscript. SA made histopathology preparation and interpretation.

\section{Declaration of conflicting interests}

The author(s) declared no potential conflicts of interest with respect to the research, authorship, and/or publication of this article.

\section{REFERENCES}

1. Gross T, Ihrke P, Walder E, Affolter VK: Skin Diseases of the Dog and Cat: Clinical and Histopathologic Diagnosis. Oxford, United Kingdom: Blackwell Science Ltd; 2005, 853865.

2. Barrett LE, Skorupski K, Brown DC, Weinstein N, Clifford C, Szivek A: Outcome following treatment of feline gastrointestinal mast cell tumours. Vet Comp Oncol 2018, 16: 188-93.

3. Brown CA, Chalmers SA: Diffuse cutaneous mastocytosis in a cat. Vet Pathol 1990, 27: 366-69.

4. Lamm CG, Stern AW, Smith AJ. Cooper EJ, Ullom SW, Campbell GA: Disseminated cutaneous mast cell tumors with epitheliotropism and systemic mastocytosis in a domestic cat. J Vet Diagn Invest 2009, 21: 710-715.

5. Colombo S, Scarampella F, Ordeix L, Roccabianca P: Dermatophytosis and papular eosinophilic/mastocytic dermatitis (urticaria pigmentosa-like dermatitis) in three Devon Rex cats. J Feline Med Surg 2012, 14: 498-502.

6. Mohri T, Takashima K, Yamaney Y, Sekiguchi M, Iwasaki T: Urticaria Pigmentosa in a Cat. J Anim Clin Med 2006, 15: 131-134.

7. Noli C, Colombo S, Abramo F, Scarampella F: Papular eosinophilic/mastocytic dermatitis (feline urticaria pigmentosa) in Devon Rex cats: A distinct disease entity or a histopathological reaction pattern? Vet Dermatol 2004, 15: 253-259.

8. Tomich LM, Pieper JB: Urticaria pigmentosa-like skin disease in a domestic shorthair cat. J Feline Med Surg Open Reports 2019, 5: 1-4.

9. Vitale CB, Ihrke PJ, Olivry T, Stannard AA: Feline urticaria pigmentosa in three related Sphinx cats. Vet Dermatol 1996, 7: 227-33.

10. Frank RK, Galvan BA, Schoell AR: Use of oclacitinib (Apoquel, Zoetis) for treatment of cutaneous mastocytosis in a cat. Vet Dermatol 2014, 25: 153.

11. Szczepanik M, Wilkołek P, Śmiech A, Taszkun I: Diffuse cutaneous mastocytosis (pigmented maculopapular Cutaneous mastocytosis) in a cat. Mac Vet Rev 2020, 43: 81-83. 


\section{URTICARIA PIGMENTOSA IZAZVANA SA MICROSPORIUM CANIS KOD SFINKS MAČKE - PRIKAZ SLUČAJA}

SZCZEPANIK Marcin, WILKOŁEK Piotr, KALISZ Grzegorz, ŚMIECH Anna

Na pregled je primljena mačka, rase sfinks stara dve godine, nekastrirana sa simptomima multiplih eritematoznih papula sa hiperpigmentacijom. Biopsijom kože, u dermisu uočene su jasno diferentovane monomorfne mast ćelije. Na kulturi za gljivice, uzorak je bio pozitivan na Microsporium canis. Postavljena je dijagnoza - urticaria pigmentosa kao posledica infekcije sa $M$. canis. Životinja je uspešno tretirana itrakonazolom (oralno) kao i sa šamponom koji je sadržavao hlorheksidin i mikonazol. Prema saznanju autora, radi se o prvom prikazanom slučaju "pigmentisane urtikarije", nastale usled infekcije sfinks mačke dermatofitom. 